\title{
Reflection of Customer Experience and Destination Image of Tourist Trust through Satisfaction Mediation
}

\author{
Ika Barokah Suryaningsih ${ }^{\mathrm{a}, *}$, Kristian Suhartadi Widi Nugraha ${ }^{\mathrm{a}}$, Arnas Yulio Sukmalangga ${ }^{\mathrm{a}}$ \\ ${ }^{a}$ Faculty of Economics and Business, University of Jember, Jember
}

\begin{abstract}
In the tourism services sector, tourist experience and destination image are the keys to create tourist satisfaction. Thus, tourists are expected to gain pleasure and lead to a build of tourists' trust in the beach destination. Research objectives are to prove the effect of customer experience and destination image on trust through the mediation of tourist satisfaction. The population was all tourists who had visited a beach in Trenggalek Regency more than two times. The sampling technique used was accidental sampling with 193 respondents. Data collection was carried out by a questionnaire containing statement items that were given a score of 1-5 using a Likert scale, and the analysis tool was to use PLS. The results imply that customer experience and destination image affect tourist satisfaction. Tourist experience was not significant on trust, but the destination image influences the trust of the tourist. On the other hand, tourist satisfaction affects tourists' trust. This research proves that the more satisfied tourists, it would be to increase tourist' trust. The Sobel test shows that the intervening variable, namely tourist satisfaction, can mediate the influence of the variable of tourist experience and destination image on trust when visiting the beach.
\end{abstract}

Keywords: tourist' experience, destination image, satisfaction, trust, tourism

\section{INTRODUCTION}

Indonesian tourism currently continues to grow in line with government policies that make the tourism sector as a revenue of the Indonesian economy. The implementation of tourism development carried out by Indonesia is running the "Visit Indonesia" program launched since 2008. The branding of Indonesian' tourism today is "Wonderful Indonesia" or "Enchantment of Indonesia". The Wonderful Indonesia Program is an effort to promote Indonesian tourism.

East Java is one of the provinces in Indonesia with a high level of tourist arrivals and has increased from time to time. The Government's plan to open a new path in the form of the Southern Cross Line (SCL) through Prigi and Popoh Beaches that can connect the two attractions, is expected to facilitate the relationship between Trenggalek Regency and Tulungagung Regency to increase the number of tourists.

Indonesian tourism currently continues to grow in line with government policies that make the tourism sector as a revenue of the Indonesian economy. The implementation of tourism de-

*Author in correspondence,

Email address: barokah.feb@unej.ac.id (Ika Barokah Suryaningsih)

ISSN: 2549-3221 (Print) 2549-323X (Online)

DOI: $10.26487 /$ hebr.v4i1.2329 velopment carried out by Indonesia is running the "Visit Indonesia" program launched since 2008. The branding of Indonesian' tourism today is "Wonderful Indonesia" or "Enchantment of Indonesia". The Wonderful Indonesia Program is an effort to promote Indonesian tourism.

East Java is one of the provinces in Indonesia with a high level of tourist arrivals and has increased from time to time. The Government's plan to open a new path in the form of the Southern Cross Line (SCL) through Prigi and Popoh Beaches that can connect the two attractions, is expected to facilitate the relationship between Trenggalek Regency and Tulungagung Regency to increase the number of tourists.

Trenggalek Regency is one of the areas that are active in promoting and developing tourism. Trenggalek Regency has a lot of beaches tourism potential. The beach attractions in Watulimo Subdistrict Trenggalek Regency are Karanggongso Beach, Prigi Beach and Damas Beach. One of the beaches visited by local tourists is Pelang, Prigi, and Karanggongso Beach.

Increased visits to attractions do not just happen, but stimuli are needed through the formation of an impressive image and experience at a destination. Creating an experience is an effective way to form an excellent response to marketing stimuli provided by tourism service businesses. Tourism activities here are more interactive because tourism service businesses create entertainment and attractions what a stand out in the creation of 
experience (Kartajaya and Nirwandar, 2013).

The process of tourist experience began with the interaction between tourists and visited tourist destinations, where the interaction causes a reaction from tourists to the attraction of attractions. Rini (2009), argues that consumer experience involves the five senses, heart, mind, which can place purchases of products or services among the broader contexts in life.

Pine and Gilmore (2012) define customer experience as an event that binds the customer personally as something fun, binding, cannot be forgotten because it consumes things related to the experience. Furthermore, the experience of tourists significantly affects tourist satisfaction (Suryaningsih and Sumani, 2018).

In addition to the experience of visiting tourists, several previous studies have shown a relationship between destination images and tourist satisfaction, such as research conducted by Bigné et al. (2001). The results showed that there was a significant positive effect between destination images on satisfaction.

Trust is a valuable asset for triggering one's loyalty. Barnes (2003) states that trust is a belief that someone will find what they want in others, and not what he did. Another opinion states that trust is knowledge held by consumers, and conclusions consumers make about objects, attributes, and benefits (Yao et al., 2019).

Trust interpreted as a willingness to rely on the ability, integrity, and motivation of other parties to act in order to satisfy one's needs and interests as agreed together implicitly or explicitly (Tjiptono, 2016) and customer experience influences Customer Trust (Felita and Japarianto, 2015).

The results of Şahin et al. (2011) and Utama (2017), showed satisfaction affect trust significantly. Furthermore, it also explains the search for information about the destination by tourists before visiting can capture the promise of promotion that the destination will be in line with tourist expectations, and will not act detrimental to tourists. After visiting tourists will evaluate the performance of the destination, that is, if the performance of the destination is perceived following its promises, the tourists will be satisfied. Satisfaction will give birth to the trust of tourists.

Results of research by Pertiwi et al. (2017) and Putra (2017) show that satisfaction becomes the mediating variable of various independent variables such as experience and image of trust. This is also supported by several findings that satisfaction can be a mediating variable as reviewed by Weiermair (2000), Utama (2017) and Suryaningsih and Sumani (2018).

Based on the phenomena, the objective of this study is to prove the effect of customer experience and destination image on trust through the mediation of tourist satisfaction.

\section{LITERATURE REVIEW}

\subsection{The Effect of Tourist Experience on Satisfaction}

Pine and Gilmore (2012) defines customer experience as an event that binds the customer personally as something fun, binding, cannot be forgotten because it consumes things related to the experience. The experiences are entertain and create positive memories that will trigger customers to revisit and recommend to friends and family ((Chen et al., 2018), (Light, 2017); (Zatori et al., 2018)). The experience of tourists has a significant effect on tourist satisfaction. Thus the hypothesis can be formulated:

$H_{1}$ : Tourist Experience has a significant effect on Tourist Satisfaction.

\subsection{The Effect of Destination Image on Satisfaction}

Destination Image, according to Hanif et al. (2016), is the trust that tourists have about a product or service that tourists buy or will buy. Destination imagery is not always formed from experience or facts. However, it can be constructed so that it becomes a strong motivating or driving factor for tourists to travel to a tourism distortion. This is confirmed by research conducted by Utama (2017), Wang et al. (2009), Bigné et al. (2001), Chi and Qu (2008), and Prayag and Ryan (2012) that destination image affect tourist satisfaction. However, the results of Amalia and Murwatiningsih (2016) research, that destination image does not directly influence satisfaction. Based on the description, the hypotheses put forward are as follows:

$$
\mathrm{H}_{2} \text { : Destination image affects tourist satisfaction. }
$$

\subsection{The Effect of Tourist Experience on Trust}

Consumer trust is knowledge conducted by consumers, and conclusions consumers make about objects, attributes, and benefits (Felita and Japarianto, 2015), (Hamzah, 2013), (Silvestri et al., 2017). Furthermore, trust interpreted as a willingness to rely on the ability, integrity, and motivation of other parties to act in order to satisfy one's needs and interests as agreed together implicitly or explicitly (Tjiptono, 2016). Felita and Japarianto (2015) shows that Customer Experience influences Customer Trust. Based on the description, the hypothesis formulated as follows:

$\mathrm{H}_{3}$ : Tourist Experience has a significant effect on trust.

\subsection{The Effect of Destination Image on Trust}

Research results of Utama (2017) show that destination image, affect trust significantly. It was further explained that at the pre-visit stage the tourists searched for information about the destination, where one of the data captured was a promotion promise that the destination would perform following expectations and would not act detrimental to tourists. After a tourist visit, the evaluation and the results of the review can become tourists' knowledge.

If the destination is perceived following the promise of promotion, tourists will believe, and vice versa, if the destination fails to fulfill its commitments, tourists will not believe (Şahin et al., 2011), (Felita and Japarianto, 2015), (Hanif et al., 2016). Based on the description, the hypothesis formulated as follows: $\mathrm{H}_{4}$ : Destination Image effect on trust significantly. 


\subsection{The Effect of Satisfaction on Trust}

The results of Şahin et al. (2011) and Utama (2017) showed that satisfaction has a significant effect on trust. Furthermore, it also explains the search for information about the destination by tourists before visiting can capture the promise of promotion that the destination will be in line with tourist expectations, and will not act detrimental to tourists. After visiting tourists will evaluate the performance of the destination, that is, if the performance of the destination is perceived following its promises, the tourists will be satisfied. Satisfaction will give birth to the trust of tourists. Based on the description, the hypothesis can be formulated:

$H_{5}$ : Satisfaction affect trust significantly.

\subsection{The Tourist Experience and Destination Image on Trust through Satisfaction}

Results of research by Pertiwi et al. (2017); and Putra (2017) show that satisfaction becomes the mediating variable of various independent variables such as experience and image of trust. This is also supported by several findings that satisfaction can be a mediating variable as reviewed by Utama (2017), Papadimitriou et al. (2015), Wang et al. (2009), Silvestri et al. (2017), and Suryaningsih and Sumani (2018). Based on various previous research findings, the hypotheses proposed are:

$H_{6}$ : Tourist satisfaction is a mediating variable between tourist experience and destination image of trust.

\section{RESEARCH METHOD}

The population in this study were all tourists who had visited beach tourism in Trenggalek Regency more than two times. The sampling technique used was accidental sampling with 193 respondents. The research data was collected in SeptemberDecember 2019 on three beaches in Trenggalek, namely Pelang, Prigi, and Karanggongso beaches.

Data collection is carried out on several time options, namely on weekdays, and on holidays including weekends, Christmas holidays, and towards the end of the year. Furthermore, the measurement scale of the data uses a Likert level start from strongly disagree (point 1) to agree strongly (point 5 ).

The type of research in this study is explanatory research and used the Partial Least Square (PLS) method as an analytical tool. PLS was used to measure the relationship of each item with its construct variable (Solimun, 2011). This study uses indicators in the measurement of each construct that is structural, and then the appropriate analytical tool is PLS with the application of SmartPLS 3.3. Sobel test is used to test how much the role of the variable $\mathrm{z}$ mediates the effect of exogen on endogen Ghozali (2016).

\section{FINDINGS AND ANALYSIS}

The goodness of fit is carried out using an outer model and inner model evaluation as follows:
Table 1: Discriminant Validity and Composite Reliability

\begin{tabular}{llclll}
\hline \hline \multirow{2}{*}{ Variable } & \multicolumn{2}{l}{$\begin{array}{l}\text { Discriminant } \\
\text { Validity }\end{array}$} & & $\begin{array}{l}\text { Composite } \\
\text { Reliability }\end{array}$ & \\
\cline { 2 - 6 } & AVE & Descp. & $\begin{array}{c}\text { Cronbach } \\
\alpha\end{array}$ & Descp. \\
& & & & \\
\hline $\begin{array}{l}\text { Tourist } \\
\text { Experi- } \\
\text { ence }\end{array}$ & 0.675 & Valid & 0.847 & 0.89 & Reliable \\
$\begin{array}{l}\text { Destination } \\
\text { Image }\end{array}$ & 0.697 & Valid & 0.856 & 0.9 & Reliable \\
$\begin{array}{l}\text { Satisfaction } \\
\text { Trust }\end{array}$ & 0.767 & Valid & 0.848 & 0.91 & Reliable \\
\hline
\end{tabular}

1. Outer model. Convergent validity is the level of validity of the indicator can be seen based on the loading factor value. Based on the result, the loading factor value of all research indicators is more significant than 0.5 . Thus, all indicators of research variables are valid. Discriminant validity is a comparison of the square root of average variance extracted (AVE) value of each construct with the correlation between other constructs in the model, and the recommended measurement value must be higher than 0.50 (Solimun, 2011). While composite reliability is an index to show the extent to which a measuring device can be trusted to be relied upon so that a latent variable has excellent composite reliability if it has composite reliability with a cut-off value of 0.7 .

Based on the results in Table 1, it is known that the AVE score in this study $\geq \alpha=0.50$. Therefore, it shows that all variables are valid. Besides, all variables in this study had a Composite Reliability score of $\geq \alpha=0.70$, so the research instrument of all variables is reliable. Cronbach Alpha values in all variables $\geq \alpha=0.70$ indicate that the consistency of respondents' answers in one latent variable is consistent.

2. Inner Model

Testing the inner model is done to see the relationship between the construct, the significance value, and the Rsquare. Evaluation of inner models can be done in three ways. The third way is to look at R-square, Q-square, and Goodness of Fit. The R-square of satisfaction is 0,153 and trust is 0,872 . Testing the inner model further by looking at the value of Q-square, the quantity of Q-square must be in the range of $0<Q^{2}<1$. The formula of $\mathrm{Q}-$ Square: $Q^{2}=1-\left(1-R_{1}^{2}\right)\left(1-R_{2}^{2}\right)$

Predictive relevance value is obtained $Q^{2}=0.891$ or $89.1 \%$. It indicates that the model can explain the phenomenon of research by $89.1 \%$. Therefore, the model can be said to be good or has good predictive value so that it can be used for hypothesis testing. Structural model equations are formulated to determine the relationship between the latent variables studied. 


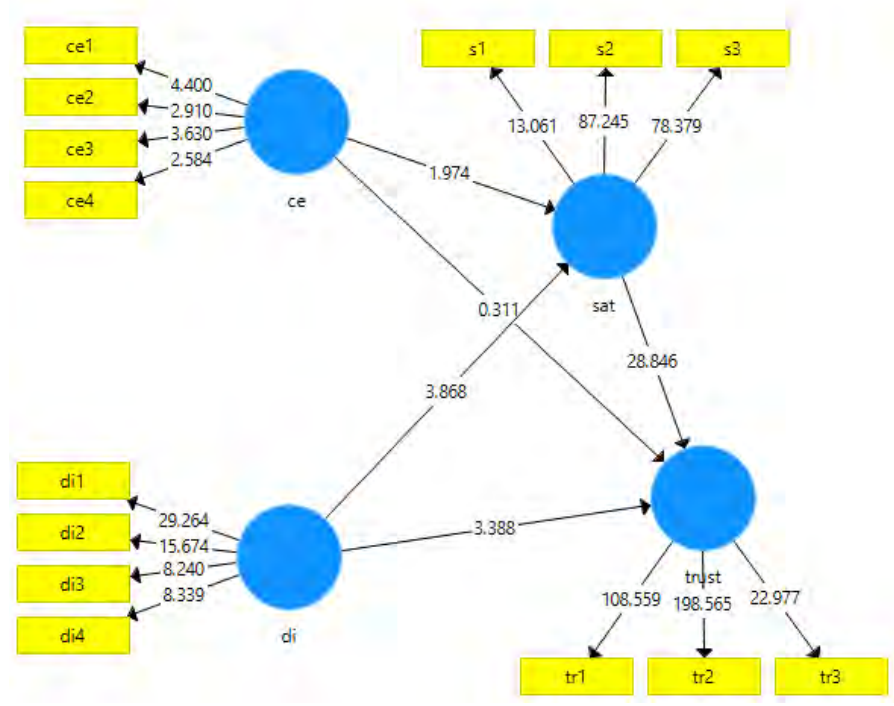

Figure 1: Pathway Construction

$$
\begin{gathered}
\text { Satisfaction }=0.306 C E+0.391 D I+\zeta \\
\text { Trust }=0.012 C E+0.177 D I+0.869 S a t+\zeta
\end{gathered}
$$

The construction of the path diagram is to combine the inner model and the outer model using SmartPLS Software, as shown in Figure 1.

Hypothesis testing is done by the bootstrapping resampling method. The direct and indirect effects of hypothesis testing are presented in the Table 2.

Tourist experience affects satisfaction significantly with a path coefficient of 0.306 and a p-value of $0.049 \alpha=0.05$, so $H_{1}$ is accepted. However, $H_{2}$ in this study is proven by assessing the coefficient of destination image on satisfaction, having a significant positive effect. It can be seen in the magnitude of the coefficient value of 0.391 and p-value of $0.000 \leq \alpha=0.05$. Tourist experience has no significant effect on trust; this is evidenced by the path coefficient of 0.012 and p-value of $0.756 \geq$ $\alpha=0.05\left(H_{3}\right.$ is rejected $)$.

Destination image affects trust positive significantly, so $H_{4}$ is accepted. It is evidenced by the path coefficient of 0.177 and p-value of $0.000 \leq \alpha=0.05$. Furthermore, satisfaction affects trust positive significantly with a coefficient value of 0.869 and p-value $0.000 \leq \alpha=0.05$, so $H_{5}$ is accepted.

The specific indirect effects shows that tourist experience influences trust through satisfaction, this is indicated by the coefficient value of 0.326 and $\mathrm{p}$-value of $0.012 \leq \alpha=0.05$. The exciting thing is that the destination image has no direct effect on trust. However, the mediating role of tourist satisfaction can make the destination image influence trust. The coefficient value of the indirect effect of destination image on trust is 0.339 , and the $\mathrm{p}$-value is $0.000 \leq \alpha=0.05$.

The calculation result of the Sobel Test shows absolute Zvalue $(23.476)>1.98$ with a significance level of $5 \%$, proving that the intervening variable can mediate the influence of exogenous variables on endogenous. Thus, the satisfaction variable is determined to be able to mediate the variable of tourist experience and destination image of tourists' trust in Pelang, Prigi, and Karanggongso Beaches.

\subsection{The Effect of Tourist Experience on Satisfaction}

The path analysis on the t-test of the first hypothesis shows that Tourist Experience influences Tourist Satisfaction by looking at the significance level of 0,000. Based on the characteristics of tourist respondents based on gender, most tourists are women. Meanwhile, tourists are mostly teenagers and adults aged 18-29 years. The majority of tourists use private vehicles to go to Karanggongso beach from outside the city, aiming to travel with family tourists to get a positive experience and feel satisfied. Based on previous research, it can be seen that the tourist experience affect tourist satisfaction significantly on beach tourism in Trenggalek Regency.

\subsection{The Effect of Destination Image on Satisfaction}

The results of the analysis show that the image of the destination affects tourist satisfaction. The level of significance of the destination image' coefficient is equal to 0.001 . The relationship shown by the regression coefficient is positive, meaning that the better the Destination Image the Tourist Satisfaction will increase ( $H_{2}$ is accepted). The intensity of repeated visits is known that tourists have confidence in the Karanggongso beach, to be used as a place to travel, trust arises because of a feeling of satisfaction of tourists towards beach tourism in Trenggalek Regency.

\subsection{The Effect of Tourist Experience on Trust}

The path analysis on the t-test of the third hypothesis $\left(\mathrm{H}_{3}\right)$ shows the tourist experience does not affect the trust. The significance level of this coefficient is $0.756 \geq \alpha=0.05$, so $H_{3}$ is rejected.

The tourist experience is a response from within tourists that involves the five senses, emotions, and cognitive events that are memorable and difficult to forget after experiencing the experience provided. Pine and Gilmore (2012), Chen et al. (2018), and Elliott and Yannopoulou (2007) stated that tourist experience is reflected by education, aesthetics, entertainment, and escapism. The response of these tourists who became a stimulus feeling satisfied when visiting the beach. Trust is not built from direct tourist experience but must go through the satisfaction felt by tourists first.

On the other hand, trust is a tourist's belief in the ability, kindness, and integrity that is given by beach tourism management (Şahin et al., 2011); (Felita and Japarianto, 2015). The manager's ability to serve tourists, the manager's care for tourists who come, and the compatibility between promotion with the real situation must be felt by tourists to create satisfaction. If satisfaction does not occur, tourist experience cannot directly influence trust. 
Table 2: Path Coefficients and Hypothesis Testing Results

\begin{tabular}{|c|c|c|c|c|}
\hline Variable & $\begin{array}{l}\text { Path Coeffi- } \\
\text { cients }\end{array}$ & t-statistic & p-value & Description \\
\hline $\mathrm{ce} \rightarrow$ sat & 0.306 & 1,974 & 0.049 & Significant \\
\hline ce $\rightarrow$ trust & 0.012 & 0.311 & 0.756 & Not Significant \\
\hline $\mathrm{di} \rightarrow s a t$ & 0.391 & 3,868 & 0.000 & Significant \\
\hline $\mathrm{di} \rightarrow$ trust & 0.177 & 3.388 & 0.001 & Significant \\
\hline sat $\rightarrow$ trust & 0.869 & 28.846 & 0.000 & Significant \\
\hline $\mathrm{ce} \rightarrow$ sat $\rightarrow$ trust & 0.326 & 2.974 & 0.012 & Significant \\
\hline $\mathrm{di} \rightarrow$ sat $\rightarrow$ trust & 0.339 & 4.023 & 0.000 & Significant \\
\hline Sobel test (Z-score) & & 234.768 & & \multirow{3}{*}{ Significant } \\
\hline$\alpha$ & & 0.05 & & \\
\hline Z-table & & 1.98 & & \\
\hline
\end{tabular}

Note: ce:tourist' experience; di:destination image; sat:satisfaction; trust:tourist' trust

\subsection{The Effect of Destination Image on Trust}

The path analysis of the fourth hypothesis $\left(H_{4}\right)$ shows that the destination image affects tourist trust. The significance level of the path coefficient is 0.025 . Perceived tourist destinations provide compliance with the promises of promotion then it creates tourist trust, and vice versa, if the destination fails to fulfill its promises then tourists will not believe it (Sahin et al., 2011); (Felita and Japarianto, 2015); (Hanif et al., 2016). Based on previous research, it can be seen that the destination image affects tourist trust in beach tourism in the district of Trenggalek significantly.

\subsection{The Effect of Satisfaction on Trust}

The path analysis of the fifth hypothesis shows that tourist satisfaction affects tourist trust. The significance level of the path coefficient is 0,000 . It means that the better the tourist satisfaction, the tourist trust will increase $\left(H_{5}\right.$ accepted). Satisfaction is a feel of tourist who experiences the performance of a destination better than their expectations (Kotler and Keller, 2016). Customers will be satisfied if their expectations are exceeded so satisfied customers tend to remain loyal. Buy more, be less sensitive to price changes, and the talks benefit the destination.

\subsection{The Tourist Experience and Destination Image on Trust through Satisfaction}

Based on the calculation of the Sobel test in the sixth hypothesis testing $\left(H_{6}\right)$ shown in Table 2 , the absolute $\mathrm{z}$ value is $23.476>1.98$ with a significance level of $5 \%$. This proves that intervening variables can mediate the influence of exogenous variables on endogenous ( $H_{6}$ accepted). Thus, the satisfaction variable can mediate the tourist experience variable and destination image to the tourists' trust when visiting the beach in Trenggalek district.

The indirect effect of tourist experience variables through tourist satisfaction on trust has a higher coefficient than the coefficient of the indirect effect of destination image variables through tourist satisfaction on trust.
This is due to satisfaction, as defined by Kotler and Keller (2016), which is a subjective assessment of an activity or experience. Tadajewski (2010) shows that satisfaction is the life experience of action, feeling left after interaction between individuals and objects. Reisinger and Turner (2003) believe that satisfaction is the result of comparing pre-tourism expectations with post-tourist experiences. This condition then forms an experience for tourists so that it gives satisfaction when visiting the beach.

\section{CONCLUSION}

Beach tourism managers and similar tourism industries are expected to improve marketing strategies better than before. The better the marketing strategy, tourism, will remain maintained and more widely known and can develop for the better. The marketing strategy can be carried out by taking into account the facilities and needs of tourists so that tourists feel satisfied and make repeat visits.

For the local government, tourist satisfaction must be the primary concern. Tourist satisfaction will be to increase the interest of tourists to revisit intention. Tourist satisfaction is a measure of the success of a destination that is always crowded with tourists. Local government must continue to develop the tourism sector in order to further develop through increased attractiveness, amenities, and accessibility of tourist destinations.

\section{References}

Amalia, I., Murwatiningsih, 2016. Pengaruh citra destinasi dan nilai pelanggan terhadap loyalitas wisatawan melalui kepuasan wisatawan. Management Analysis Journal 5 (3), 257-268.

URL: https://journal.unnes.ac.id/sju/index.php/maj/ article/view/12579/

DOI: https ://doi.org/10.15294/maj . v5i3. 12579

Barnes, J. G., 2003. Secrets Of Customer Relationship Management (Andi (ed.)). Andi Offset, Yogyakarta.

Bigné, J. E., Sánchez, M. I., Sánchez, J., 2001. Tourism image, evaluation variables and after purchase behaviour. Tourism Management 22 (6), 607-616. URL: https : //doi.org/10.1016/S0261-5177(01)00035-8 
Chen, Y., King, B., Lee, H.-W., 07 2018. Experiencing the destination brand: Behavioral intentions of arts festival tourists. Journal of Destination Marketing and Management 10, 61-67.

URL: https://doi.org/10.1016/j.jdmm.2018.06.004

Chi, C. G. Q., Qu, H., 2008. Examining the structural relationships of destination image, tourist satisfaction and destination loyalty: An integrated approach. Tourism Management 29 (4), 624-636. URL: https://doi.org/10.1016/j.tourman.2007.06.007

Elliott, R., Yannopoulou, N., 2007. The nature of trust in brands: A psychosocial model. European Journal of Marketing 41 (9), 988-998. URL: https://doi.org/10.1108/03090560710773309

Felita, C. I., Japarianto, E., 2015. Analisa pengaruh customer experience terhadap customer loyalty dengan customer engagement dan customer trust sebagai variabel intervening di the body shop. Jurnal Manajemen Pemasaran PETRA 1 (1), 1-10.

Ghozali, I., 2016. Aplikasi Analisis Multivariate denganProgram IBM SPSS 23 (VIII). Badan Penerbit Universitas Diponegoro, Semarang.

Hamzah, Y. I., 2013. Potensi media sosial sebagai sarana promosi interaktif bagi pariwisata indonesia. Jurnal Kepariwisataan Indonesia 8 (3), 1-9. URL: http://www.kemenpar.go.id/userfiles/JKI

Hanif, A., M., K., Kholid, M., 2016. Pengaruh citra destinasi terhadap kepuasan wisatawan serta dampak terhadap loyalitas wisatawan. Jurnal Administrasi Bisnis 3 (1), 44-52.

URL: http://administrasibisnis.studentjournal.ub.ac.id/ index.php/jab/article/view/1480

Kartajaya, H., Nirwandar, S., 2013. Tourism Marketing 3.0. Gramedia Pustaka Utama, Jakarta.

Kotler, P., Keller, K. L., 2016. Marketing Management, 15th Edición. Pearson Higher Ed USA.

Light, D., 2017. Progress in dark tourism and thanatourism research: An uneasy relationship with heritage tourism. Tourism Management 61, 275-301. URL: https://doi.org/10.1016/j.tourman.2017.01.011

Papadimitriou, D., Apostolopoulou, A., Kaplanidou, K., 2015. Destination personality, affective image, and behavioral intentions in domestic urban tourism. Journal of Travel Research 54 (3), 302-315.

URL: https://doi.org/10.1177/0047287513516389

Pertiwi, A. R., Djawahir, A. H., Andarwati, A., 2017. Pengaruh brand experience terhadap brand satisfaction, brand trust, dan brand loyalty. Jurnal Manajemen Dan Kewirausahaan 5 (2), 20-35.

URL: http://jurnal.unmer.ac.id/index.php/jmdk/article/ view/1355

DOI: $10.26905 / j m d k \cdot v 5 i 2.1355$

Pine, J., Gilmore, J. H., 2012. The Experience Economy Updated Edition. Harvard Business Review Press.

Prayag, G., Ryan, C., 2012. Antecedents of tourists' loyalty to mauritius: The role and influence of destination image, place attachment, personal involvement, and satisfaction. Journal of Travel Research 51 (3), 342-356.

URL: https://doi .org/10.1177/0047287511410321
Putra, S. P. A. M., 2017. Pengaruh e-wom terhadap citra destinasi, kepuasan dan lotyalitas (studi pada kunjungan wisatawan di diy). Jurnal MODUS 29 (2), 201-218.

URL: https://ojs.uajy.ac.id/index.php/modus/article/view/ 1331

Reisinger, Turner, L. W., 2003. Cross-cultural behaviour in tourism: concepts and analysis. Butterworth Heinemann.

Rini, E. ., 2009. Menciptakan pengalaman konsumen dengan experiential marketing. Jurnal Manajemen Bisnis 2 (1), 15-20.

Silvestri, C., Aquilani, B., Ruggieri, A., 2017. Service quality and customer satisfaction in thermal tourism. TQM Journal 29 (1), 55-81. URL: https://doi.org/10.1108/TQM-06-2015-0089

Solimun, 2011. Analisis Multivariat Permodelan Struktural Metode Partial Least Square-PLS. CV. Citra Malang, Malang.

Suryaningsih, I. B., Sumani, S., 2018. The influence of financial literacy, the image of destination, the social media against the interest of visiting local tourists through the mediation of the emotional experience. European Journal of Management and Marketing Studies 3 (4), 1-18.

URL: https://oapub.org/soc/index.php/EJMMS/article/view/ 502

DOI: $10.5281 /$ zenodo. 2542742

Tadajewski, M., 2010. Towards a history of critical marketing studies. Journal of Marketing Management 26 (9), 773-824.

URL: https://doi .org/10.1080/02672571003668954

Tjiptono, F., 2016. Manajemen Pemasaran Jasa. Andi, Yogyakarta.

Utama, I. B. G. R., 2017. Pemasaran Pariwisata. Andi Offset, Yogyakarta.

Wang, X., Zhang, J., Gu, C., Zhen, F., 2009. Examining antecedents and consequences of tourist satisfaction: A structural modeling approach. Tsinghua Science and Technology 14 (3), 397-406.

URL: https : //doi.org/10.1016/S1007-0214(09)70057-4

Weiermair, K., 2000. Tourists' perceptions towards and satisfaction with service quality in the cross-cultural service encounter: Implications for hospitality and tourism management. Managing Service Quality: An International Journal 10 (6), 397-409.

URL: https ://doi.org/10.1108/09604520010351220

Yao, T., Qiu, Q., Wei, Y., March 2019. Retaining hotel employees as internal customers: Effect of organizational commitment on attitudinal and behavioural loyalty of employees. International Journal of Hospitality Management 76 (2018), 1-8.

URL: https://doi .org/10.1016/j.ijhm. 2018.03.018

Zatori, A., Smith, M. K., Puczko, L., 2018. Experience-involvement, memorability and authenticity: The service provider' s effect on tourist experience. Tourism Management 67, 111-126.

URL: https://doi.org/10.1016/j.tourman.2017.12.013

Şahin, A., Zehir, C., Kitapçi, H., 12 2011. The effects of brand experiences, trust and satisfaction on building brand loyalty; an empirical research on global brands. Procedia - Social and Behavioral Sciences 24, 1288-1301. URL: https://doi .org/10.1016/j.sbspro.2011.09.143 